\title{
Analisis Pendekatan Metode TAM Pada Penggunaan Aplikasi E-Commerce
}

\author{
Kersna Minan \\ Fakultas Ekonomi Bisnis, Universitas Harapan Medan, Medan, Indonesia \\ Email: kersnaminan@gmail.com \\ Submitted: 21/11/2021; Accepted: 28/11/2021; Published: 30/11/2021
}

\begin{abstract}
Abstrak-Perkembangan jaman juga ditandai dengan terjadinya perkembangan terhadap teknologi. Perkembangan teknologi juga tidak lepas dari kehidupan pada manusia. Hingga saat sekarang ini sudah hampir seluruh organisasi perusahaan memanfaatkan dari perkembangan pada teknologi internet tersebut. Pemanfaatan terhadap teknologi internet merupakan sebuah inovasi yang dilakukan oleh organisasi perusahaan yang dapat membantu untuk meningkatkan kinerja dan juga proses bisnis pada organisasi perusahaan. Pada masa sekarang ini kegiatan proses bisnis yang dilakukan oleh organisasi perusahaan secara virutal atau biasa disebut dengan E-Commerce. Penggunaan e-commerce sekarang ini sudah menjadi sebuah trend fenomena yang sangat tinggi. Saat ini e-commerce dibutuhkan untuk memenuhi kebutuhan masyarakat dalam era digital, e-commerce digunakan sebagai tempat pembelian produk bahkan juga jasa. Technology Acceptance Model (TAM) adalah suatu model yang digunakan untuk memberikan penawaran terhadap penerimaan penggunaan e-commerce serta perilaku bagi para penggunanya. Pada penelitian ini akan dilakukan sebuah penelitian untuk mengukur seberapa jauh aplikasi e-commerce diterima oleh masyarakat. Dan didapatkan hasil bahwa seluruh hipotesa diterima yang berarti menunjukan bahwa aplikasi e-commerce sudah diterima oleh masyarakat. Hal tersebut didukung dengan pengaruh variabel secara stimulant sebesar 79,2\%
\end{abstract}

Kata Kunci: Penggunaan; Aplikasi; E-Commerce; Metode TAM

Abstract-The development of the era is also marked by the development of technology. Technological developments are inseparable from human life. Until now, almost all corporate organizations have taken advantage of the developments in internet technology. Utilization of internet technology is an innovation carried out by corporate organizations that can help to improve performance and also business processes in corporate organizations. At this time the business process activities carried out by corporate organizations are virtual or commonly referred to as E-Commerce. The use of ecommerce has now become a very high trend phenomenon. Currently e-commerce is needed to meet the needs of society in the digital era, e-commerce is used as a place to purchase products and even services. Technology Acceptance Model (TAM) is a model used to provide an offer to the acceptance of e-commerce usage and behavior for its users. In this study, a study will be conducted to measure how far e-commerce applications are accepted by the public. And the results show that all hypotheses are accepted, which means it shows that the e-commerce application has been accepted by the community. This is supported by the influence of the variable stimulant of $79.2 \%$.

Keywords: Usage; Application; E-Commerce; TAM Method

\section{PENDAHULUAN}

Perkembangan jaman juga ditandai dengan terjadinya perkembangan terhadap teknologi. Perkembangan teknologi juga tidak lepas dari kehidupan pada manusia. Dengan adanya teknologi seluruh kegiatan aktifitas manusia dapat dibantu penyelesaiannya secara efektif dan juga efisian. Selain teknologi sebagai salah satu kepentingan dan kebutuhan manusia dalam kehidupan untuk membantu dalam mempermudah aktifitas kegiatan, teknologi juga digunakan sebagai kebutuhan mobilitas dalam kemudahan akses yang dilakukan oleh manusia tersebut(Ferdira et al., 2018).

Dengan pesatnya pada perkembangan teknologi tersebut tentu banyak memperngaruhi banyak sektor seperti kesehatan, pendidikan, pelayanan, bisnis serta juga ekonomi. Teknologi internet merupakan salah satu perkembangan teknologi yang sudah banyak dimanfaatkan oleh sektor - sektor tersebut. Hingga saat sekarang ini sudah hampir seluruh organisasi perusahaan memanfaatkan dari perkembangan pada teknologi internet tersebut(Sitohang, 2020).

Pemanfaatan terhadap teknologi internet merupakan sebuah inovasi yang dilakukan oleh organisasi perusahaan yang dapat membantu untuk meningkatkan kinerja dan juga proses bisnis pada organisasi perusahaan(Oktapiani et al., 2020). Dimana pada masa sekarang ini proses bisnis yang dilakukan sudah tidak dilaksanakan secara face to face tetapi proses bisnis dimasa sekarang ini sudah beralih secara virtual. Proses bisnis secara virtual dilakukan dengan pemanfaatan teknologi tersebut dilakukan oleh pembeli dan juga penjual pada tempat yang berbeda - beda pada sebuah media yang sama(Faizah et al., 2021).

Pada masa sekarang ini kegiatan proses bisnis yang dilakukan oleh organisasi perusahaan secara virutal atau biasa disebut dengan E-Commerce. E-Commerce merupakan sebuah marketplace yang digunakan sebagai tempat transaksi komersil yang melibatkan pertukaran nilai dilakukan pada media teknologi internet oleh setiap individua ataupun organisasi(Prasetianingrum \& Sejati, 2017). Aplikasi e-commerce sendiri juga melibatkan banyak hal seperti internet, website, smartphone. E-commerce adalah perpaduan antara proses bisnis dengan teknologi informasi dimana pebisnis atau perusahaan dengan pelanggan perorangan maupun perusahaan melakukan transaksi elektronik secara online. Dalam 
transaksi online, pembeli tidak dapat melihat produk secara kasat mata, namun dapat mengetahuinya melalui informasi yang diberikan oleh penjual(Santoso \& Edwin Zusrony, 2020)

Penggunaan e-commerce sekarang ini sudah menjadi sebuah trend fenomena yang sangat tinggi. Hal tersebut didasarkan oleh survey yang dilakukan oleh Badan Pusat Statistik menunjukan bahwa pengguna e-commerce tumbuh cukup pesat dalam beberapa tahun belakangan ini. Peranan dari e-commerce ini juga sangat membantu pada pertumbuhan ekonomi di Indoneisa. Dengan adanya e-commerce ini dapat menjangkan proses transaksi bisnis secara meluas dengan mudah dan tanpa membutuhkan waktu yang lama(Anthony \& Sama, 2021).

Saat ini e-commerce dibutuhkan untuk memenuhi kebutuhan masyarakat dalam era digital, e-commerce digunakan sebagai tempat pembelian produk bahkan juga jasa. Perkembangan teknologi memungkinkan para pelaku bisnis di Indonesia mengembangkan kegiatan bisnisnya untuk tetap menjaga hubungan baik dengan para pelanggan(Anthony \& Sama, 2021). Selain itu e-commerce juga memberikan beberapa keuntungan terhadap pelaku bisnisnya. Bagi produsen akan sangat efisien untuk mengetahui informasi mengenai kompetisi harga pada pasar. Selain itu juga e-commerce juga menyediakan proses transaksi bisnis yang bersifat cashless atau nontunia yang artinya proses pembayaran dapat dilakukan dengan melakukan pembayaran virtual dengan berbagai macam teknologi pendukungnya(Salsabila Putri \& Zakaria, 2020). Bagi konsumen e-commerce juga memberikan keuntungan seperti banyaknya diskon atau flashsale yang diberikan oleh produsen serta mudahnya bagi konsumen untuk melakukan pencarian terhadap produk yang akan dibeli(Wahidin et al., 2021).

Sudah banyak situs jasa yang menyediakan tempat untuk melakukan transakasi jual beli secara online seperti Shoope, Lazada, Tokopedia, Bukalapak, BliBli dan lain sebagainya. Peningkatan dalam penggunaan layanan ini meningkat setiap harinya, sehingga dapat membantu untuk mengingkatkan perekonomian secara besar. Dengan semakin marak dan meningkatnya penggunaan layanan jual beli onine e-commerce penelitian ini melakukan penelusuran terhadap pengguaan e-commerce(Budiastuti \& Muid, 2020).

Technology Acceptance Model (TAM) adalah suatu model yang digunakan untuk memberikan penawaran terhadap penerimaan penggunaan e-commerce serta perilaku bagi para penggunanya. Technology Acceptance Model didefinisikan sebagai salah satu model untuk menganalisis dan memahami faktor-faktor yang mempengaruhi diterimanya penggunaan teknologi informasi pada masyarakat. TAM bertujuan untuk menjelaskan dan memperkirakan penerimaan (acceptance) pengguna dan faktor-faktor yang mempengaruhi penerimaan terhadap suatu teknologi dalam suatu organisasi. TAM menjelaskan hubungan sebab akibat antara keyakinan dan perilaku, tujuan/keperluan, serta penggunaan aktual dari pengguna/user suatu sistem informasi.

Ada dua konsep utama dalam user acceptance (penerimaan pengguna) yaitu perceived ease of use (persepsi kemudahan) dan perceived usefulness (persepsi kemanfaatan). Perceived ease of use didefinisikan sebagai tingkat kepercayaan seseorang bahwa penggunaan teknologi sistem informasi (e-commerce) akan mudah dan tidak membutuhkan usaha yang keras. Perceived usefulness didefinisikan sebagai tingkat kepercayaan seseorang bahwa penggunaan sistem informasi (e-commerce) meningkatkan kinerja dalam pekerjaannya. Penggunaan e-commerceditentukan oleh persepsi individu dan sikap yang pada akhirnya akan membentuk perilaku seseorang dalam penggunaan suatu teknologi informasi (e-commerce).

Sehingga pada penelitian ini akan dilakuan sebuah penelitian untuk melakukan pengukuran terhadap penerimaan aplikasi e-commerce dimasyarakat dimana pendekatan yang dilakukan dengan menggunakan metode pendekatan Technology Acceptance Model (TAM). Hasil akhir pada penelitian diharapkan sebagai bahan pertimbangan bagi pelaku dan pegiat e-commerce apakah e-commerce sudah diterima sepenuhnya oleh masyarakat atau belum.

\section{METODE PENELITIAN}

\subsection{E-Commerce}

Electronic Commerce (E-Commerce) adalah proses pembelian, penjualan atau pertukaran produk, jasa dan informasi melalui jaringan komputer. E-Commerce merupakan bagian dari ebusiness, dimana cakupan e-business lebih luas, tidak hanya sekedar perniagaan tetapi mencakup juga pengkolaborasian mitra bisnis, pelayanan nasabah, lowongan pekerjaan dll. Selain teknologi jaringan www, E-Commerce juga memerlukan teknologi basis data atau pangkalan data (database), e-surat atau surat elektronik (e-mail), dan bentuk teknologi non komputer yang lain seperti halnya sistem pengiriman barang, dan alat pembayaran untuk ECommerce ini(Suryawirawan, 2020).

E-Commerce singkatan dari Electronic Commerce yang artinya sistem pemasaran secara atau dengan media elektronik. E-Commerce ini mencakup distribusi, penjualan, pembelian, marketing dan servis dari sebuah produk yang dilakukan dalam sebuah sistem elektronika seperti Internet atau bentuk jaringan komputer yang lain. E-commerce merupakan kegiatan bisnis yang dijalankan secara elektronik melalui suatu jaringan internet atau kegiatan jual beli barang atau jasa melalui jalur komunikasi digital. Electronic Commerce (Perniagaan Elektronik) didefinisikan sebagai segala bentuk perdagangan/ perniagaan barang dan jasa (trade of goods and service) dengan menggunakan media elektronik(Wulan, 2015).

E-Commerce merupakan kemudahan yang dapat diakses setiap pelaku jual beli yang dilakukan secara online, ecommerce merupakan tempat seseorang prusahaan startup, perusahaan berkembang, perusahaan maju dapat memasarkan produk maupun jasa yang mereka perjual belikan dengan ketentuan kode etik IT, dengan adanya ecommerce dapat membantu pedagang-pedangang usaha mikro maupun makro dapat bekembang secara pesat dan memiliki 
jangkauan pasar yang hampir mencapai seluruh wilayah negara maupun luar negeri, e-commerce merupakan tahapan perkembangan yang meningkatkan perekonomian bangsa menjadi lebih baik lagi(Achmad, 2018).

E-commerce juga dapat mengakibatkan nilai negatif yang terkandung didalamnya dikarenakan penyalahgunaan seseorang maupun kelompok individu yang tidak bertanggung jawab, hal ini juga menyebabkan banyaknya orang-orang memiliki spesifikulasi terhadap pendapat adanya teknologi dan kemudahannya seperti ecommerce dalam dunia binis(Purnama \& Putri, 2021).

\subsection{Metode Technology Acceptance Model (TAM)}

Technology Acceptance Model (TAM) atau dalam bahasa indonesia disebut sebagai Model penerimaan teknologi adalah model yang mengadopsi theory of reasoned action (TRA) teori tindakan yang beralasan dengan satu premis bahwa reaksi dan persepsi seseorang terhadap sesuatu hal, akan menentukan sikap dan perilaku orang tersebut. Reaksi dan persepsi pengguna Teknologi Informasi (TI) akan mempengaruhi sikapnya dalam penerimaan terhadap teknologi tersebut teori ini dikembangkan oleh Fishbein dan Ajzen (1975). Teori tentang penggunaan sistem teknologi informasi yang dianggap sangat berpengaruh dan umumnya digunakan untuk menjelaskan penerimaan individual terhadap penggunaan sistem teknologi informasi.

TAM (Technology Acceptance Model) merupakan salah satu teknik yang dibuat untuk mampu melihat maupun menganalisis setiap faktor-faktor yang merupakan faktor yang mempengaruhi penerimaan teknologi komputer, terdapat banyak model yang dapat menganalisis hal yang sama seperti literatur yang meneliti tentang sikap terhadap teknologi seperti TRA, TPB, TAM. Metode TAM (Technology Acceptance Model) penting untuk diketahui karena penilaian terhadap teknologi akan membentuk penilaian seperti apa sikap seseorang, seperti apa pengaruh yang akan timbul karena penilaian seseorang terhadap teknologi dan lain-lain yang berhubungan dengan sikap terhadap teknologi komputer. Konsep pendekatan TAM meliputi(Novita \& Helena, 2021) :

\section{a. Perceived Usefulness}

Perceived Usefulness atau persepsi manfaat pengunaan adalah sejauh mana individu percaya bahwa suatu teknologi yang dipergunakan akan meningkatkan performa dari. Tingkatan dimana individu percaya atau meyakini bahwa penggunaan suatu sistem tertentu akan dapat meningkatkan prestasi kerja orang tersebut, yang dapat diartikan bahwa manfaat dari penggunaan teknologi informasi dapat meningkatkan kinerja dan prestasi kerja orang yang menggunakannya.

\section{b. Perceived Ease of Use}

Perceived Ease of Use atau persepsi kemudahan penggunaan merupakan persepsi Ease of Use yang memiliki self belief dalam menggunakan sistem TI dan tidak memerlukan free of effort atau tidak merepotkan Perceived Ease of Use merupakan suatu tingkatan dimana individu percaya bahwa dalam menggunakan sistem tertentu akan free of effort atau terbebas dari usaha.

\section{c. Attitude Towards Using}

Konsep Attitude Toward Using dalam TAM memiliki konsep sikap terhadap penggunaan sebuah sistem yang berbentuk acceptance atau rejection sebagai efek apabila individu menggunakan suatu teknologi dalam menunjang pekerjaannya. Sikap menjelaskan penerimaan seseorang terhadap teknologi informasi dimana sikap menyatakan apa yang kita sukai dan tidak, yang terdiri atas beberapa unsur diantaranya cara pandang (cognitive), afektif (affective), dan behavioral components.

\section{d. Behavioral Intention to Use}

Behavioral Intention (minat perilaku) merupakan suatu minat atau keinginan seseorang untuk melakukan suatu perilaku atau tindakan tindakan. Minat berhubungan dengan tindakan-tindakan atau perilaku-perilaku, akan tetapi keinginan dapat berubah menurut waktu, semakin lebar jarak waktu maka semakin dimungkinkan hal tersebut terjadi perubahan- perubahan minat seseorang. Tingkat penggunaan sebuah computer technology pada individu dapat diprediksi dari sikap perhatian pengguna terhadap teknologi tersebut, apabila ada keinginan untuk menambah peripheral pendukung, motivasi untuk tetap menggunakan, serta minat untuk memotivasi pengguna lainnya.

\section{e. Actual System Use}

Kondisi nyata penggunaan sistem (actual system usage) dikonsepkan dalam bentuk pengukuran terhadap frekuensi dan durasi waktu penggunaan teknologi. Setiap orang akan merasa puas apabila menggunakan sistem apabila mereka merasa yakin bahwa sistemnya mudah digunakan dan akan meningkatkan produktifitasnya yang tergambarkan dalam kondisi actual system.

\subsection{Penelitian Terdahulu}

Berikut ini adalah hasil penelitian yang telah dilakukan oleh beberapa peneliti baik di Indonesia maupun negara lain seperti yang terlihat pada tabel berikut ini:

Tabel 1. Penelitian Terdahulu

\begin{tabular}{|c|c|c|c|c|}
\hline No & Nama & Judul & Hasil & Sumber \\
\hline 1 & $\begin{array}{l}\text { (Rachbini et al., } \\
\text { 2019) }\end{array}$ & $\begin{array}{l}\text { Analisis Niat Pembelian Ulang } \\
\text { E-Comerce Mobile dengan }\end{array}$ & $\begin{array}{l}\text { praktisi } \text { e-commerce } \\
\text { memberikan perhatian lebih pada } \\
\text { penyederhanaan customer journey dan }\end{array}$ & $\begin{array}{l}\text { Jurnal } \\
\text { Aplikasi } \\
\text { Bisnis dan }\end{array}$ \\
\hline
\end{tabular}




\begin{tabular}{|c|c|c|c|c|}
\hline No & Nama & Judul & Hasil & Sumber \\
\hline \multirow{4}{*}{2} & \multirow{4}{*}{$\begin{array}{l}\text { (Santika \& Yadna, } \\
\text { 2017) }\end{array}$} & $\begin{array}{l}\text { Pendekatan } \quad \text { Technology } \\
\text { Acceptance Model (TAM) }\end{array}$ & $\begin{array}{l}\text { mampu mengkomunikasikan aspek } \\
\text { kredibilitas dan kepercayaan dengan } \\
\text { baik ke consumer market agar mampu } \\
\text { dipahami dan dapat meyakinkan } \\
\text { konsumen atau pelanggan bahwa e- } \\
\text { commerce mobile platform merupakan } \\
\text { tempat berbelanja yang kredibel (dapat } \\
\text { dipercaya). }\end{array}$ & $\begin{array}{l}\text { Manajemen } \\
\text { Vol. } 5 \text { No. } 3\end{array}$ \\
\hline & & Technology & Hasil penelitian menunjukkan bahwa & \multirow{3}{*}{$\begin{array}{l}\text { Prosiding } \\
\text { Seminar } \\
\text { Nasional } \\
\text { AIMI }\end{array}$} \\
\hline & & Acceptance Model Terhadap & pengaruh antar & \\
\hline & & $\begin{array}{l}\text { Penggunaan E-Commerce Pada } \\
\text { UKM Kerajinan Di Gianyar }\end{array}$ & $\begin{array}{l}\text { memiliki pengaruh positif dan } \\
\text { siginifikan. }\end{array}$ & \\
\hline \multirow[t]{6}{*}{3} & \multirow[t]{6}{*}{ (Lesmono, 2015) } & Pengaruh Penggunaan E- & Dari penelitian yang dilakukan hasil & Jurnal \\
\hline & & Commerce & dari variabel pada Metode TAM & Evolusi Vol. \\
\hline & & Pengembangan Usaha Kecil & menunjukan bahwa E-Commerce & 3 No. 1 \\
\hline & & Menengah (Ukm) Dengan & memiliki pengaruh yang cukup besar & \\
\hline & & Technology & terhadap perkembangan UKM & \\
\hline & & Acceptance Model & & \\
\hline \multirow[t]{10}{*}{4} & \multirow[t]{10}{*}{ (Yulistia, 2017) } & Analisis Pengaruh Efektivitas & Penelitian ini menguraikan hasil & \multirow{10}{*}{$\begin{array}{l}\text { JATISI } \\
\text { (Jurnal } \\
\text { Teknik } \\
\text { Informatika } \\
\text { dan Sistem } \\
\text { Informasi) } \\
\text { Vol. } 4 \text { No. } 1\end{array}$} \\
\hline & & Dan Manfaat & penelitian mengenai sejauh mana sikap & \\
\hline & & Terhadap Sikap Dan Perilaku & dan perilaku pengguna dalam hal ini & \\
\hline & & Pengguna & adalah sektor UKM di Palembang, & \\
\hline & & Menggunakan Metode TAM & dalam memanfaatkan teknologi & \\
\hline & & (Studi Kasus: & informasi dalam bentuk E-Commerce & \\
\hline & & Palembang) & $\begin{array}{l}\text { dengan menggunakan metode Theory } \\
\text { Acceptance Model(TAM), sehingga }\end{array}$ & \\
\hline & & & bisa diketahui seberapa jauh & \\
\hline & & & keefektifan dan manfaat sistem E- & \\
\hline & & & $\begin{array}{l}\text { Commerce dalam membantu sebagai } \\
\text { media penjualan dan pembelian secara } \\
\text { online. }\end{array}$ & \\
\hline
\end{tabular}

\subsection{Pendekatan Penelitian}

Penelitian ini berlandaskan penelitan yang menggunakan data primer diambil langsung melalui responden. Jenis data yang digunakan dan diolah merupakan data kuantitatif. Responden pada penelitan sebanyak 30 orang. Kemudahan, sikap, norma, kontrol dan lingkungan digunakan sebagai variable penelitian untuk mengukur SiBisa pada masyarakat.

\subsection{Teknik Analisis Data}

Jenis data dalam penelitian ini adalah data kuantitatif yang. Data dikumpulkan menggunakan survey / kuesioner dan data diolah menggunakan SPSS. Kuesioner berisikan pertanyaan berdasarkan dengan Skala Likert. Teknis analisis data yang digunakan dalam penelitian ini yaitu dengan menggunakan analisis komparatif yaitu suatu teknik dengan menggunakan uji rata-rata atau uji beda dengan perlakuan yang tidak sama.

1. Hipotesis :

HO $=$ (Terdapat pengaruh Perceived Usefulness terhadap penggunaan E-Commerce)

$\mathrm{H} 1=($ Terdapat pengaruh Perceived Ease of Use terhadap penggunaan E-Commerce $)$

$\mathrm{H} 2=($ Terdapat pengaruh Attitude Towards Using terhadap penggunaan E-Commerce $)$

H3 = (Terdapat pengaruh Behavioral Intention to Use terhadap penggunaan E-Commerce $)$

$\mathrm{H} 4=$ (Terdapat pengaruh Actual System Use terhadap penggunaan E-Commerce)

2. Uji Instrumen

Uji instrument terdiri dari uji Validasi dan Uji Reliabilitas

a. Uji Validitas

Validitas berasal dari kata validity yang mempunyai arti sejauh mana ketepatan dan kecermatan suatu instrumen pengukur dalam melakukan fungsi ukurnya. Jika alat tersebut menjalankan fungsinya dengan baik dan benar, maka angka validitasnya dapat dikatakan tinggi. Artinya, hasil pengukuran tersebut merupakan besaran yang mengacu pada fakta atau keadaan yang sesungguhnya. Tes validitas menunjuk kepada fungsi pengukuran suatu tes. Suatu tes validitas, memfokuskan masalah pada apakah tes itu benar mengukur apa yang ingin diukur. Artinya adalah, bagaimana tes itu dapat mengungkapkan dengan benar ciri-ciri yang dimiliki oleh suatu obyek ukur. Pengujian ini menggunakan rumus Korelasi Pearson. Dengan ketentuan :

i. hitung r-hitung > r-tabel, maka setiap item yang berisikan pertanyaan kuisioner dapat dikatakan valid. 
ii. dan Jika nilai r-hitung < r-tabel, maka setiap item yang berisikan pertanyaan kuisioner dapat dikatakan tidak valid.

b. Uji Reliabilitas

Reliabilitas berasal dari kata reliability yang memiliki arti seberapa besar hasil pengukuran itu dapat dipercaya. Reliabilitas ukuran menyangkut seberapa jauh skor individu, skor-z, relative konsisten apabila dilakukan pengulangan pengadministrasian dengan tes yang sama. Reliabilitas konsistensi gabungan butir berkaitan dengan tingkat kesempurnaan antara butir yang ada. Pengambilan keputusan dalam uji reliabilitas ini menggunakan Cronbach's Alpha dengan ketentuan sebagai berikut:

i. Jika Cronbach Alpha nilai > r-tabel, berarti data kuesioner dikatakan konsisten dan dapat dipercaya.

ii. Jika nilai Cronbach's Alpha < r-tabel, berarti data kuesioner dikatakan tidak konsisten dan tidak dapat dipercaya.

3. Uji statistik yang digunakan adalah uji $\mathrm{t}$ :

$$
t_{\text {hitung }}=\frac{\overline{\mathrm{X}}_{\mathrm{A}}-\overline{\mathrm{X}}_{\mathrm{B}}}{\sqrt{\frac{\mathrm{s}_{\mathrm{A}} \mathrm{n}_{\mathrm{A}}}{\mathrm{n}_{\mathrm{A}}}+\frac{\mathrm{s}_{\mathrm{B}}}{\mathrm{n}_{\mathrm{B}}}}} \text { atau } \mathrm{t}_{\text {hitung }}=\frac{\overline{\mathrm{X}}_{1}-\overline{\mathrm{X}}_{2}}{\mathrm{~s} \sqrt{\frac{1}{\mathrm{n}_{1}}+\frac{1}{\mathrm{n}_{2}}}}
$$

Dibandingkan dengan $\mathrm{t}_{\text {tabel }}= \pm \mathrm{t}(\alpha / 2, \mathrm{nA}+\mathrm{nB}-2$ dengan derajat kesalahan $\alpha=10 \%)$

4. Kriteria uji

Terima $\mathrm{H}_{0}$, jika $-\mathrm{t}_{\mathrm{t}} \leq \mathrm{th} \leq \pm \mathrm{t}_{\mathrm{t}}$ hal lain tolak $\mathrm{h}_{0}$ dengan kurva distribusi normal

5. Kesimpulan

Terima atau tolak Ho. Karena penelitian mengelola data dengan menggunakan software maka dikatakan signifikan, jika nilai sig $<$ dari kesalahan $\alpha=10 \%$.

\section{HASIL DAN PEMBAHASAN}

Hasil penelitian merupakan hasil akhir gabungan dari latar belakang masalah, hipotesis, pengumpulan data dan pengujian literatur dengan menggunakan metode analisis data yang dilaksanakan pada objek penelitian untuk mencari titik penyelesaian permasahalan yang dihadapai.

Dari penjelasan diatas Metode Survey ialah dengan menyebarkan kuesioner secara online yang melibatkan secara langsung terhadap pengguna aplikasi e-commerce sebanyak 30 kuesioner. Berikut gambaran umum secara menyeluruh terkait hasil pengumpulan data responden yang menjadi subjek penelitian ini yang berdasarkan usia

Tabel 2. Karakteristik Responden

\begin{tabular}{ccccc}
\hline No & Karakteristik & Responden & Total & $\%$ \\
\hline \multirow{2}{*}{1} & Jenis Kelamin & Pria & 19 & $63 \%$ \\
& & Wanita & 11 & $37 \%$ \\
& & $<17$ Tahun & 5 & $17 \%$ \\
2 & Usia & $17-22$ Tahun & 9 & $30 \%$ \\
& & $23-28$ Tahun & 7 & $23 \%$ \\
& & $29-34$ Tahun & 6 & $20 \%$ \\
& & $35-40$ Tahun & 2 & $7 \%$ \\
& & $>41$ Tahun & 1 & $3 \%$ \\
3 & Pekerjaan & Wiraswasta & 2 & $7 \%$ \\
& & PNS & 5 & $17 \%$ \\
& & TNI/Polri & 0 & $0 \%$ \\
& & Pelajar/Mahasiswa & 14 & $47 \%$ \\
& & Karyawan Swasta & 8 & $27 \%$ \\
4 & Intensitas Penggunaan E- & Lain-lain & 1 & $3 \%$ \\
& Commerce Dalam 1 Bulan & 2 s/d Kali Kali & 9 & $30 \%$ \\
& & $>5$ Kali & 3 & $60 \%$ \\
& & & $10 \%$ \\
\hline
\end{tabular}

\subsection{Uji Validitas dan Reabilitas Instrumen}

Sebelum dilakukan penyebaran kuesioner kepada para responden, terlebih dahulu dilakukan uji validtas dan juga realibilitas terhadap instrument yang digunakan

Tabel 3. Uji Validitas dan Reliabilitas Instrumen

\begin{tabular}{lccccc}
\hline \multicolumn{1}{c}{ Variabel } & Koefisien & R Tabel & Validtas & Cronbach's Alpha & Reliabilitas \\
\hline Perceived Usefulness & 0,883 & & Valid & & \\
Perceived Ease of Use & 0,784 & \multirow{2}{*}{0,361} & Valid & \multirow{2}{*}{ Valid } & \multirow{2}{*}{ Realiabel } \\
Attitude Towards Using & 0,779 & & Valid & & \\
Behavioral Intention to Use & 0,821 & & & \\
\hline
\end{tabular}




\begin{tabular}{cccccc}
\hline Variabel & Koefisien & R Tabel & Validtas & Cronbach's Alpha & Reliabilitas \\
\hline Actual System Use & 0,779 & & Valid & & \\
\hline
\end{tabular}

\subsection{Uji T dan Uji F}

Setelah dilakukannya Uji Validitas dan juga Uji Reliabilitas pada instrument penelitian. Tahapan langkah yang dilakukan seterusnya adalah melakukan pengujian terhadap Uji T dan Uji F. Uji T dan Uji F dilakukan untuk melakukan pengujian terhadap hipotesa. Apakah hipotesa yang sudah dijabarkan dapat diterima ataupun ditolak. Adapun untuk Uji T dapat dilihat pada tabel berikut

Tabel 4. Uji T

\begin{tabular}{|c|c|c|c|c|c|c|}
\hline & & Coef & cients $^{a}$ & & & \\
\hline & & Unstandardize & Coefficients & $\begin{array}{c}\text { Standardized } \\
\text { Coefficients }\end{array}$ & & \\
\hline Model & & B & Std. Error & Beta & $\mathrm{t}$ & Sig. \\
\hline 1 & (Constant) & .129 & .913 & & .141 & .889 \\
\hline & Perceived Usefulness & 144 & .102 & 207 & 2.409 & .172 \\
\hline & Perceived Ease of Use & 190 & .121 & .241 & 2.562 & .131 \\
\hline & Attitude Towards Using & 170 & .113 & .228 & 2.502 & 146 \\
\hline & Behavioral Intention to Use & 297 & .108 & .430 & 3.761 & .011 \\
\hline & Actual System Use & .167 & .121 & .206 & 2.382 & .180 \\
\hline
\end{tabular}

Berdasarkan dari hasil Uji T yang telah dilakukan bahwasannya nilai batas untuk Uji T adalah 2,060. Berdasarkan hasil yang telah didapatkan bahwasaannya secara keseluruhan Hipotesis diterima. Bahwasannya seluruh variabel yang digunakan pada penelitian berpengaruh terhadap penggunaan aplikasi SiBisa.

Tabel 5. Uji F

\begin{tabular}{llrrrrr}
\hline & & \multicolumn{3}{c}{ ANOVA $^{\mathbf{a}}$} & & \\
Model & & Sum of Squares & df & Mean Square & F & Sig. \\
\hline 1 & Regression & 4.409 & 5 & .882 & 5.438 & $.002^{\mathbf{b}}$ \\
& Residual & 3.891 & 24 & .162 & & \\
& Total & 8.300 & 29 & & &
\end{tabular}

a. Dependent Variable: Puas

b. Predictors: (Constant), Actual System Use, Perceived Ease of Use, Perceived Usefulness,

Attitude Towards Using, Behavioral Intention to Use

Berdasarkan dari hasil Uji F yang telah dilakukan bahwasannya nilai batas untuk Uji F adalah 2,53 dengan nilai sig $<0,05$. Berdasarkan hasil yang telah didapatkan bahwasaannya secara keseluruhan Hipotesis diterima. Bahwasannya seluruh variabel yang digunakan pada penelitian berpengaruh terhadap penggunaan aplikasi e-commerce.

\section{KESIMPULAN}

Setelah dilakukan seluruh proses anlisa pada penelitian maka didapatkan hasil penelitian bahwasannya variabel oleh pendekatan TAM Perceived Usefulness, Perceived Ease of Use, Attitude Towards Using, Behavioral Intention to Use dan Actual System Use berpengaruh dalam penggunaan aplikasi e-commerce. Hipotesis penelitian diterima dengan hasil bahwa Masyarakat sudah puas dengan penggunaan, pemanfaatan serta kehadiran aplikasi e-commerce dan Masyarakat sudah mendapatkan kemudahan terhadap penggunaannya. Hal tersebut didukung dengan pengaruh variabel secara stimulant sebesar $79,2 \%$.

\section{REFERENCES}

Achmad, A. (2018). Pengaruh Pengguna E-commerce terhadap Transaksi Online Menggunakan Konfirmasi faktor Analisis. Faktor Exacta, 11(1), 7-16. https://doi.org/10.30998/faktorexacta.v11i1.2306

Anthony, L., \& Sama, H. (2021). Studı Kualıtatıf Mengena1 Faktor Penerımaan Aplıkası E-Commerce Shopee Dan Fintech Shopeepay Bag1 Masyarakat Sen1or. Journal Conference on Management, Business, Innovation, Education and Social Science, 1(1), 678686.

Budiastuti, A. D. P., \& Muid, D. (2020). ANALISIS FAKTOR-FAKTOR PENGARUH MINAT PENGGUNAAN SISTEM INFORMASI AKUNTANSI BERBASIS E-COMMERCE PADA APLIKASI SHOPEE DENGAN MENGGUNAKAN TECHNOLOGY ACCEPTANCE MODEL (TAM). Diponegoro Journal of Accounting, 9(4), 1-10. http://ejournals1.undip.ac.id/index.php/accounting

Faizah, O. A., Suparti, \& Hoyyi, A. (2021). ANALISIS TECHNOLOGY ACCEPTANCE MODEL PADA APLIKASI PLATFORM SHOPEE DENGAN PENDEKATAN PARTIAL LEAST SQUARE (STUDI KASUS PADA MAHASISWA UNIVERSITAS DIPONEGORO). Jurnal Gaussian, 10(3), 423-434. 
Ferdira, B. G., Gulo, A. P. N., Nugroho, Y. I. D., Fernandes, J., \& Andry. (2018). ANALISIS PERILAKU PENGGUNA APLIKASI MOBILE MATAHARIMALL.COM MENGGUNAKAN TECHNOLOGY ACCEPTANCE MODEL (TAM) Bryan. Jurnal Sistem Informasi Dan Tenologi, 1(2), 107-116.

Lesmono, I. D. (2015). Pengaruh Penggunaan E-Commerce Bagi Pengembangan Usaha Kecil Menengah (Ukm) Dengan Pendekatan Technology Acceptance Model. Evolusi, 3(1), 49-60.

Novita, D., \& Helena, F. (2021). Analisis Kepuasan Pengguna Aplikasi Traveloka Menggunakan Metode Technology Acceptance Model ( TAM ) Dan End-User Computing Satisfaction ( EUCS ). JTSI, 2(1), 22-37.

Oktapiani, Y., Rosario, M., \& Nehemia, A. (2020). Analisis Minat Penggunaan Aplikasi Brimo Dengan Pendekatan Technology Acceptance Model ( TAM ). Ilmiah Mahasiswa Sistem Informasi, 2(3), 249-260.

Prasetianingrum, S., \& Sejati, F. R. (2017). ANALISIS TECHNOLOGY ACCEPTANCE MODEL (TAM) TERHADAP PENERAPAN E-COMMERCE DI UKM KOTA JAYAPURA. FUTURE JURNAL MANAJEMEN DAN AKUNTANSI, 5(1), 5263. http://repository.unika.ac.id/id/eprint/20248

Purnama, N. I., \& Putri, L. P. (2021). Analisis Penggunaan E - Commerce Di Masa Pandemi. Seminar Nasional Teknologi Edukasi Dan Humaniora, 1(1), 553-558.

Rachbini, W., Salim, F., Haque, M. G., \& Rahmawati, E. (2019). Analisis Niat Pembelian Ulang E-Comerce Mobile dengan Pendekatan Technology Acceptance Model (TAM). Jurnal Aplikasi Bisnis Dan Manajemen, 5(3), 530-540. https://doi.org/10.17358/jabm.5.3.530

Salsabila Putri, A., \& Zakaria, R. (2020). Analisis Pemetaan E-Commerce Terbesar Di Indonesia Berdasarkan Model Kekuatan Ekonomi Digital. Seminar Dan Konferensi Nasional IDEC, 1(November), 1-14.

Santika, I. W., \& Yadna, I. P. (2017). ANALISIS TECHNOLOGY ACCEPTANCE MODEL TERHADAP PENGGUNAAN ECOMMERCE PADA UKM KERAJINAN DI GIANYAR. Prosiding Seminar Nasional AIMI, Oktober, 27-28.

Santoso, B., \& Edwin Zusrony. (2020). Analisis Persepsi Pengguna Aplikasi Payment Berbasis Fintech Menggunakan Technology Acceptance Model (Tam). Jurnal Teknologi Informasi Dan Komunikasi, 11(1), 49-54. https://doi.org/10.51903/jtikp.v11i1.150

Sitohang, N. (2020). Penerapan Terhadap Model Penerimaan Teknologi (TAM) Dengan Penerimaan Aplikasi E-Commerce Dalam Kehidupan Bisnis Usaha Mikro Masyarakat. Journal of Trends Economics and Accounting ..., 1(2), 44-50. https://journal.fkpt.org/index.php/jtear\%0Ahttps://journal.fkpt.org/index.php/jtear/article/view/69

Suryawirawan, O. A. (2020). PENGALAMAN BERBELANJA DI E-COMMERCE TERHADAP NIATAN MAHASISWA UNTUK MENGADOPSI E- COMMERCE DI MASA DEPAN: PENDEKATAN TAM DAN SELF-EFFICACY. SEIKO : Journal of Management \& Business, 3(3), 129-142.

Wahidin, M., Setiyani, L., \& Alfredo, A. (2021). Analisis Tingkat Penerimaan Merchant ShopeePay Di Karawang Menggunakan Pendekatan Technology Accetance Model ( TAM ) Pendahuluan. Seminar Nasional: Inovasi \& Adopsi Teknologi, September, 226-235.

Wulan, R. (2015). Analisis Transaksi E-Commerce Melalui Jaringan Media Sosial Mobile. Jurnal Sosio-E-Kons, 7(3), $239-245$.

Yulistia, Y. (2017). Analisis Pengaruh Efektivitas Dan Manfaat E-Commerce Terhadap Sikap Dan Perilaku Pengguna Dengan Menggunakan Metode TAM (Studi Kasus: UKM Kota Palembang). JATISI (Jurnal Teknik Informatika Dan Sistem Informasi), 4(1), 93-100. https://doi.org/10.35957/jatisi.v4i1.91 